CROCHIK, José Leon. Preconceito, indivíduo e cultura. 2. ed. São Paulo: Robe Editorial, 1997. 152 p.

\title{
Sônia Cristina Vermelho*
}

"Como o desprezo pela subjetividade, pela fragilidade, pela razão e pela experiência são características dos preconceituosos, pensamos que uma educação voltada para a subjetividade, mas não exclusivamente, para a reflexão e para o incentivo à experiência possa conter 0 antídoto que permita, ao menos, frear a destrutividade presente no preconceito".(p. 148)

Assim Crochik termina sua discussão em torno da relação do preconceito, do indivíduo e da cultura. Nesse texto, produzido a partir de um olhar sociopsicológico sobre o indivíduo e a sociedade, o preconceito é entendido como resultado do processo de socialização, e, portanto, sofre alteração ao longo do tempo, em função das diferenças culturais e dos condicionantes históricos. A sociedade atual vem exigindo dos sujeitos um crescente processo de adaptação ao real em face da necessidade de lutar cotidianamente pela sobrevivência, o preconceito, enquanto mecanismo psíquico, tem surgido como resposta aos conflitos presentes nessa luta. Com isso, o preconceito não está somente ligado aos aspectos do objeto fruto do preconceito, mas tem profunda relação com as necessidades que se encontram no sujeito preconceituoso. Nesse sentido, o autor indica a necessidade de repensarmos o processo de formação, como indicado ao final do texto, pois quanto maior a dificuldade do sujeito em experimentar e refletir sobre o objeto ou sobre o próprio real, maior será sua necessidade de defesa frente aos objetos que lhe causam estranheza. Isso ocorre, no interior de uma leitura freudiana, porque o estranho se mostra demasiado familiar ao sujeito, portanto, "(...) o medo frente ao desconhecido, ao diferente, é menos produto daquilo que não conhecemos, do que daquilo que não queremos e não podemos re-conhecer em nós mesmos através dos outros." (p. 14)

Nesse contexto, Crochik afirma que a forma mais característica do sujeito se relacionar com a sociedade é por meio do estereótipo, entendendo este como um elemento do preconceito. $\mathrm{O}$ estereótipo é um produto de nossa cultura que se relaciona com mecanismos psíquicos infantis, quando do seu processo de diferenciação com o mundo externo. $\mathrm{O}$ autor, ao abordar os vários fatores que contribuem para a utilização do estereótipo, encontra na busca pela eficiência da ação, na obrigatoriedade da certeza, no estabeleci-

Mestrado em Educação da PUCPR.

Rua Guairicana, n. ${ }^{\circ}$ 140, Uberaba, Curitiba - PR, CEP 81550320.

E-mail: vermelho@rla01.pucpr.br

Revista Diálogo Educacional, Curitiba, v. 4, n.8, p.125-126, jan./abr. 2003. 
mento de um "valor de troca do eu no mercado" e do pensamento por clichês, os mecanismos centrais da formação do preconceito ou em outras palavras de um pensamento estereotipado. Esses mecanismos são utilizados pelos sujeitos, pois ao não conseguir entender a complexidade do real, lança mão de um pensamento estereotipado, ou seja, simplifica o real, para poder se relacionar com o mesmo. Todo esse processo é colocado ao sujeito como exigência para que este consiga suportar o sofrimento, gerado por uma cultura que se revela dissociada de seus membros, uma cultura que mostra sua irracionalidade ao colocar em primeiro plano o atendimento à interesses que são alheios e, muitas vezes, contrários aos de seus membros. Com isso, “(...) a violência sutil ou manifesta exercida pelo preconceituoso é a resposta a uma violência sutil ou manifesta gerada inicialmente pela cultura".(p. 44)

Com isso, se a formação do preconceito se dá como resultado do processo de formação do indivíduo, a educação, como uma das instâncias formadoras da nossa sociedade, assume um papel importante na luta contra 0 preconceito. Mas, como critica Crochik, se a educação visar apenas a introjeção de valores e conhecimentos sem que esses valores e conhecimentos possam ser refletidos pelos sujeitos, então, ela estará favorecendo muito mais a constituição de mecanismos psíquicos, os quais mantém o indivíduo num estágio infantil, ou de menoridade social, "(...) e assim favorecer o desenvolvimento do preconceito". (p. 34-5). Assim, como nos instiga Crochik, paradoxalmente, uma educação que se volta para atender, prioritariamente, as necessidades do mercado de trabalho, o qual, face às mudanças tecnológicas e organizacionais, vem formando pessoas para um mercado que tem necessitado cada vez menos de pessoas para produzir, coloca, ainda mais, o sujeito numa situação de conflito interno e externo e, de outro lado, aquilo da educação que vai além de sua dimensão mercadológica "(...) traz a marca da inutilidade, que se associa à superficialidade com que é transmitida, perdendo, assim, a possibilidade de levar o aluno a refletir sobre a inutilidade que marca a todos nós, uma vez que cada vez mais somos prescindíveis, isto é, substituíveis." (p. 124).

Com essas reflexões Crochik traz uma discussão extremamente fecunda e provocativa para todos nós, não só para os educadores, mas para a sociedade em geral, pois trata de temas que diz respeito a nós próprios.

Recebido em: 2/12/2002

Aprovado em: 15/2/2003 